\title{
Seasonal weight loss and metabolic adaptation in rural Beninese women: the relationship with body mass index
}

\author{
BY J. WERNER SCHULTINK ${ }^{1,2}$ JOOP M. A. VAN RAAIJ2 AND \\ JOSEPH G. A. J. HAUTVAST ${ }^{2}$ \\ ${ }^{1}$ Section of Nutrition and Food Science, Faculty of Agricultural Sciences, Benin National \\ University, PB526, Cotonou, Republic of Benin \\ ${ }^{2}$ Department of Human Nutrition, Wageningen Agricultural University, PO Box 8129, $6700 \mathrm{EV}$ \\ Wageningen, The Netherlands
}

(Received 30 December 1991 - Accepted 9 January 1993)

\begin{abstract}
A large variation in seasonal weight loss between individuals exists in rural communities in developing countries. Therefore, it was investigated whether some individuals show a metabolic adaptation and, through that, prevent large body-weight losses during the preharvest season. Basal metabolic rate (BMR), energy intake and physical activity level (PAL) of rural Beninese women were measured in three seasons. Groups of subjects were: women with a body mass index $(B M I)<18(n 18)$, and a BMI $>23$ $(n 16)$, and women who had shown small $(n 18)$ and large $(n 15)$ preharvest weight loss. All groups of subjects decreased energy intake during the preharvest season by 0.66-1.09 MJ/d. PAL did not show significant seasonal changes in any of the four groups. Only subjects with a BMI $<18$ decreased BMR during the preharvest season with 2.9 (SD 6.7) $\mathrm{J} / \mathrm{kg}$ per $\min (P<0.05)$, with a decrease of 0.8 (SD 1.4) $\mathrm{kg}$ $(P<0.05)$ in body weight. In very thin women with a BMI $<17(n$ 5) BMR expressed per unit body weight decreased even more during the preharvest season (by $12 \%$ ).
\end{abstract}

Basal metabolic rate: Body weight: Body mass index: Rural Beninese women

Rural populations in developing countries often experience important seasonal changes in food availability (Annegers, 1973; Teokul et al. 1986; Ferro-Luzzi et al. 1987). In peasant communities a period of food shortage usually occurs at the end of the rainy season just before the main food harvest. Therefore, during the preharvest season people may come into a state of negative energy balance (energy intake minus energy expenditure) resulting in a loss of body weight. Preharvest weight loss of rural populations usually corresponds to $2-5 \%$ of their body weight (Ferro-Luzzi, 1990). However, within the same community the variation between individuals in preharvest weight loss is large, and is related to body mass index (weight/height ${ }^{2}$; BMI; Ferro-Luzzi et al. 1990; Schultink et al. 1990). A large between-individual variation in preharvest weight loss suggests either that not all individuals experience the same seasonal food shortage, or that individuals may change their energy expenditure to different levels.

When during the preharvest period body weight is lost, energy expenditure is decreased because of a lowered metabolic rate (provided lean body tissue has been lost). Another way to decrease energy expenditure is by changing the physical activity pattern, or by metabolic adaptation without changing weight or activity. A change in activity pattern is an effective mechanism but it is reported that farmer populations have to increase energy expenditure during the preharvest season due to a higher agricultural labour demand (Bleiberg et al. 1980; Brun et al. 1981). The possibility of metabolic adaptation, as demonstrated by a fall 
in basal metabolic rate (BMR) per unit lean body mass, is known to exist (Keys et al. 1950). However, it is unclear whether metabolic adaptation can occur in individuals who are not changing body weight and who experience relatively small decreases in energy intake.

The aim of the present study was to investigate whether preharvest weight losses are only related to reductions in energy intake or also to reductions in energy expenditure caused by metabolic adaptation. This question was studied by measuring body weight, BMR, energy intake and energy expenditure in different seasons in two groups of women with a different BMI, and in two groups of women who showed a difference in preharvest weight loss in a previous year.

\section{SUBJECTS AND METHODS}

\section{Study area}

The study was carried out in five villages in the rural district of Dogbo in the south-western region (Mono province) of the Republic of Benin, West Africa. The district is situated $70 \mathrm{~km}$ from the coast at an altitude of $80 \mathrm{~m}$ above sea level. Each of the research villages has about 1100 inhabitants who are subsistence farmers. Mean annual rainfall is $1050 \mathrm{~mm}$, which is mainly distributed over two rainy seasons: a long rainy season from March to May, and a short rainy season from September to October. The main food crops are maize, cassava, oil palms and beans. Cultivation is done by men as well as women using hoes; the women cultivate their own fields. The staple food maize is harvested twice yearly in July and in December. Sowing of maize is carried out in March and in September. Weeding is mainly carried out in April and in October. Women usually do the housekeeping, take care of the children, prepare food, gather fire wood and fetch water. Almost all women have some small money-earning activities such as selling meals and snacks, palm oil and cassava meal.

\section{Study design and subjects}

At the start of the study in December 1987 body weight, height and skeletal diameters were measured for 150 women from the five research villages (thirty from each village). BMI was calculated from their weight and height. Subsequently, the body weights of all women were measured every 2 weeks until October 1988. For each woman the preharvest weight loss was calculated as the difference between the mean value of the two highest successive weight recordings in January-February (post-harvest season) and the mean value of the two lowest successive weight recordings in May-June (preharvest season).

In December 1987 forty women (BMI group) were selected from the total group of 150 women on the basis of their initial BMI: twenty women with a BMI $<18$ and twenty women with a BMI $>23$. In these women BMR, upper arm circumference and skinfold thicknesses, food intake and physical activity level (PAL) were measured in three different seasons: January-February 1988 (post-harvest), May-June 1988 (preharvest), August-September 1988 (post-harvest) (Fig. 1).

In December 1988 another group of forty women (weight-loss group) was selected from the whole group of 150 women on the basis of their preharvest weight loss in 1988: twenty women with a small preharvest weight loss $(<0.7 \mathrm{~kg})$ and twenty women with a larger preharvest weight loss $(>1.5 \mathrm{~kg})$. In these women the same measurements were carried out according to the same procedures as those for the BMI group. The measurements took place in comparable seasons but 1 year later: January-February 1989, May-June 1989, September-October 1989. In addition body weight was measured every 2 weeks from January 1989 to November 1989.

All eighty selected women had farming as their main occupation, they were aged $20-45$ years, had two to five children and the age of the youngest child was at least 9 months (these 
Table 1. Characteristics of rural Beninese adult female subjects

(Mean values and standard deviations)

\begin{tabular}{|c|c|c|c|c|c|c|c|c|}
\hline & \multicolumn{4}{|c|}{ BMI group } & \multicolumn{4}{|c|}{$\begin{array}{l}\text { Wt-loss group (preharvest wt loss } \\
\text { in previous year) }\end{array}$} \\
\hline & \multicolumn{2}{|c|}{$\begin{array}{c}\mathrm{BMI}<18 \\
\quad(n 18)\end{array}$} & \multicolumn{2}{|c|}{$\begin{array}{c}\mathrm{BMI}>23 \\
(n 16)\end{array}$} & \multicolumn{2}{|c|}{$\begin{array}{l}\text { Small } \\
(n 18)\end{array}$} & \multicolumn{2}{|c|}{$\begin{array}{l}\text { Large } \\
(n 15)\end{array}$} \\
\hline & Mean & SD & Mean & SD & Mean & SD & Mean & SD \\
\hline Age (years) & $41 \cdot 3$ & $10 \cdot 2$ & $39 \cdot 3$ & $8 \cdot 3$ & $32 \cdot 1$ & $3 \cdot 9$ & $31 \cdot 6$ & $6 \cdot 8$ \\
\hline $\mathrm{Wt}(\mathrm{kg})^{*}$ & $44 \cdot 0$ & $5 \cdot 1$ & $64 \cdot 0$ & $7 \cdot 5$ & $48 \cdot 7$ & $5 \cdot 5$ & $53 \cdot 4$ & $7 \cdot 1$ \\
\hline Height $(\mathrm{m})$ & 1.59 & 0.07 & $1 \cdot 57$ & 005 & 1.57 & 0.06 & 1.59 & 0.07 \\
\hline BMI $\left(\mathrm{kg} / \mathrm{m}^{2}\right)^{*}$ & $17 \cdot 2$ & $1 \cdot 0$ & $25 \cdot 8$ & $2 \cdot 4$ & $19 \cdot 7$ & $1 \cdot 5$ & $21 \cdot 3$ & $2 \cdot 5$ \\
\hline Sum of wrist diameters (mm) & 99 & 8 & 102 & 6 & 96 & 9 & 101 & 8 \\
\hline Sum of knee diameters (mm) & 161 & 10 & 166 & 11 & 162 & 9 & 174 & 10 \\
\hline Shoulder diameter (mm) & 336 & 21 & 344 & 17 & 336 & 20 & 344 & 19 \\
\hline
\end{tabular}

BMI, body mass index (wt/height ${ }^{2}$ ).

* Start of study: December 1987 for BMl group, January 1989 for preharvest weight-loss group.

criteria were used to select the whole group of 150 women). At the beginning of the study all women were non-pregnant. The data of women who became pregnant during the study period were excluded from the present analysis. Due to reasons of pregnancy, illness and moving, a complete data set covering the whole study period became available from eighteen women with a $\mathrm{BMI}<18$, from sixteen women with a BMI $>23$, from eighteen women with small preharvest weight loss and from fifteen women with larger preharvest weight loss. More characteristics of the women are given in Table 1.

\section{Body weight and anthropometry}

The two-weekly body-weight measurements took place in the villages between 07.00 and 08.30 hours using SECA platform spring balances which were attached to a solid wooden board. The balances were placed on a horizontal level and were checked before each weighing with calibration weights of 40.0 and $60.0 \mathrm{~kg}$. The women were wearing a minimum of clothing and body weight was measured to the nearest $100 \mathrm{~g}$ (no correction was made for clothing which weighed at most about $300 \mathrm{~g}$ ). Measurements were made by trained local assistants. Height was measured with the women standing on a horizontal surface against a wall with the heels together, chin tucked in and stretched upwards to full extent with the head in a Frankfurt plane. The heels, buttocks and shoulders were in contact with the wall to which a flexible metal tape had been fixed. Readings were made to the nearest $5 \mathrm{~mm}$. Skeletal diameters were measured using a Holtain skeletal anthropometer. Upper arm circumference was measured midway between the tip of the shoulder and the elbow, with the arm hanging loosely by the side, using a flexible metal tape.

Skinfold thicknesses (biceps, triceps, sub-scapular and suprailiac) were measured in triplicate using a Holtain calliper (Holtain Ltd, Crymych, Dyfed, UK) immediately after the BMR measurements were finished. The four skinfolds equation of Durnin \& Womersley (1974) was used to estimate body fat percentage. 


\section{Basal metabolic rate}

BMR was measured in three successive seasons in each year (see Fig. 1) by the same method. In each season BMR was measured on $2 \mathrm{~d}$ within the same week ( $1 \mathrm{~d}$ between the $2 \mathrm{~d}$ of measurement). BMR measurements were carried out in a small field laboratory where body weight was measured at the same time. The subjects were transported to the laboratory by car at about 07.30 hours, having been asked not to work or eat beforehand. After lying down quietly for $30 \mathrm{~min}$, BMR was measured by open-circuit indirect calorimetry using the Douglas bag technique. The women wore nose clips and breathed through a respiratory valve. Expired air was collected for three $10 \mathrm{~min}$ periods with intervals of $2 \mathrm{~min}$ between each collection. The volume of the expired air was measured with a precision wet-type gas meter (Schlumberger Meterfabriek BV, Dordrecht, The Netherlands). $\mathrm{O}_{2}$ concentration was measured in samples of expired air with a paramagnetic Servomex $\mathrm{O}_{2}$ analyser (Type OA 570; Taylor Instrument Analytics Ltd, Crowborough, Sussex). The $\mathrm{O}_{2}$ analyser was calibrated with outside air and $100 \% \mathrm{~N}_{2}$, and checked against a calibration gas of known composition. Metabolic rate was calculated using Weir's (1949) equation. Room temperature at the time of measurement varied from 26 to $31^{\circ}$ (habitual range for these women) and air pressure ranged between 754 and $764 \mathrm{mmHg}$.

Since BMR was measured in triplicate on $2 \mathrm{~d}$, six measurements were made for each woman in each season. In the three seasons in 1988 there were no significant systematic differences between the three measurements within the same day (average values being ( $\mathrm{kJ}$ (kcal in parentheses)/min) : $3.85(0.92), 3.89(0.93), 3.89(0.93)$ for the first, second and third measurement respectively), or between the $2 \mathrm{~d}(3.85(0.92)$ and $3.89(0.93)$ for the first and second day respectively). Therefore, for each woman in each period the average of the six measurements (or in case a value was missing the average of the remaining measurements) was used for further analysis. In the three seasons in 1989 there was again no difference between the $2 \mathrm{~d}$ (for both days $3.89 \mathrm{~kJ}(0.93 \mathrm{kcal}) / \mathrm{min}$, but there existed a small but statistically significant difference between the three measurements within the same day $3.93(0.94), 3.89(0.93), 3.89(0.93) \mathrm{kJ}(\mathrm{kcal}) / \mathrm{min}$, for the first, second and third measurements respectively). There was no evidence for a difference between the second and third measurements, but the first measurement was significantly higher than the other two measurements. Again the average of six measurements was used for further analyses, but in case one measurement value was missing the missing value was estimated using a model accounting for systematically higher values of the first measurement compared with the second and third measurements, assuming no difference between the second and third measurements and between the $2 \mathrm{~d}$ of measurement. The reproducibility of the BMR measurements as based on triplicate measurements (ignoring the small systematic differences in 1989) was 6.0\% (coefficient of variation; CV) in 1988 and 6.1\% (CV) in 1989.

\section{Food intake}

Food intake was determined for each subject in the same season as BMR during 4 consecutive days in each season. The time interval between measurement of BMR and the measurement of food intake in the same subject was a maximum of 2 weeks. Food intake was measured using the observed precise weighing record method (Bingham et al. 1988). All food was weighed before and after cooking, as well as the subject's portion of it, to the nearest $1 \mathrm{~g}$ using a digital balance (Soehnle Type 8000) for weights up to $1 \mathrm{~kg}$. Weights above $1 \mathrm{~kg}$ were weighed to the nearest $25 \mathrm{~g}$ on a mechanical balance (Soehnle Type 1201). The measurements were carried out by local assistants who were well known in the villages, and who stayed with the subjects from 07.30 hours until the time the subjects had eaten their dinner (usually around 20.00 hours). Foodstuffs which were eaten when the assistants 
were not present were determined using the recall method. To calculate metabolizable energy intake, food composition tables for tropical foodstuffs were used (Woot Tsuen, 1970; Platt, 1979). No extra correction was made for unavailable carbohydrates because of lack of adequate data. Metabolizable energy intake for each subject in each season was obtained by calculating the average intake of 4 consecutive days.

\section{Physical activity level}

PAL (James \& Schofield, 1990) was measured on the same days as the food intake. PAL was calculated on the basis of recorded daily physical activity patterns. Recording was done by the local assistants using minute-to-minute registration (Durnin \& Passmore, 1967). It was explained emphatically to the subjects that they should continue to carry out their habitual daily tasks while the assistants were present. The recall method was used to determine activities carried out when the assistants were not present. For the sake of simplicity physical activities were divided into eight categories: (1) sleeping and resting activities (sleeping, sitting quietly, standing quietly, light work in sitting position); (2) light activity (taking care of children, washing dishes, cleaning house); (3) moderate activity (sweeping, washing clothes); (4) heavy activity (gathering fire wood, fetching water); (5) preparation of food; (6) eating; (7) walking; (8) doing field work (clearing the field, using the hoe, harvesting).

For each day the period of time (min) spent on each activity category was calculated and the results were averaged over the $4 \mathrm{~d}$ period for each season. The PAL was calculated for each women in each period using estimated energy costs of each category of activities, based on values published by the World Health Organization (1985). These energy costs are expressed as a multiple of BMR and are respectively: $1 \cdot 2 \times \mathrm{BMR}, 2 \cdot 2 \times \mathrm{BMR}, 3 \cdot 2 \times \mathrm{BMR}$, $4.1 \times \mathrm{BMR}, 1.8 \times \mathrm{BMR}, 1.5 \times \mathrm{BMR}, 3.0 \times \mathrm{BMR}, 3.5 \times \mathrm{BMR}$.

\section{Statistical analysis}

Differences in body weight and body fat mass between post- and preharvest seasons were tested using Wilcoxon's matched-pairs signed-ranks test (Snedecor \& Cochran, 1980). To determine statistically significant seasonal changes in BMR, energy intake and PAL, analysis of variance for repeated measurements was used (MANOVA in SPSS/PC + V2.0; SPSS, 1986). When MANOVA revealed significant $F$ values $(P<0.05)$ a paired $t$ test was used to compare values of the different seasons. Differences between average values (BMR, energy intake, PAL) for two groups of subjects were tested by unpaired $t$ tests (Snedecor \& Cochran, 1980).

\section{RESULTS}

\section{Body weight and anthropometry}

Results of the measurements of body weight, body fat and upper arm circumference are presented in Table 2 . For women with a BMI $<18$ body weight in May-June (preharvest) was 0.8 (SD 1.4) kg $(P<0.05)$ lower than that in January-February (post-harvest), for women with a BMI $>23$ the decrease was 1.7 (SD 3.2) $\mathrm{kg}(P<0.08)$. Fat mass and upper arm circumference of women with a BMI $<18$ did not show significant changes. Fat mass of women with a BMI $>23$ in May-June (preharvest) was 1.6 (SD 1.9) $\mathrm{kg}(P<0.01)$ lower than that in January-February (post-harvest). Women who had shown small preharvest weight loss did not change their body weight significantly during the three seasons of measurements. The body weight of subjects who had shown a large preharvest weight loss 
Table 2. Body weight and body composition in three different seasons for rural Beninese women +

(Mean values and standard deviations)

\begin{tabular}{|c|c|c|c|c|c|c|c|c|}
\hline \multirow[b]{3}{*}{ Season } & \multicolumn{4}{|c|}{ BMI group } & \multicolumn{4}{|c|}{$\begin{array}{l}\text { Wt-loss group (preharvest wt loss } \\
\text { in previous year) }\end{array}$} \\
\hline & \multicolumn{2}{|c|}{$\begin{array}{l}\mathrm{BMI}<18 \\
\quad(n 18)\end{array}$} & \multicolumn{2}{|c|}{$\begin{array}{c}\mathrm{BMI}>23 \\
(n 16)\end{array}$} & \multicolumn{2}{|c|}{$\begin{array}{l}\text { Small } \\
(n 18)\end{array}$} & \multicolumn{2}{|c|}{$\begin{array}{l}\text { Large } \\
\left(\begin{array}{ll}n & 15\end{array}\right)\end{array}$} \\
\hline & Mean & SD & Mean & $\mathrm{SD}$ & Mean & SD & Mean & SD \\
\hline \multicolumn{9}{|l|}{ Jan-Feb (post-harvest) } \\
\hline Wt $(\mathrm{kg})$ & $44 \cdot 9^{*}$ & $5 \cdot 0$ & $65 \cdot 0$ & $7 \cdot 7$ & $48 \cdot 8$ & $5 \cdot 5$ & $53 \cdot 5$ & $7 \cdot 0$ \\
\hline Percentage fat & $20-3$ & $4 \cdot 8$ & $32 \cdot 8^{* *}$ & $4 \cdot 3$ & $24 \cdot 4^{*}$ & $4 \cdot 9$ & $25 \cdot 8$ & $6 \cdot 3$ \\
\hline Fat mass $(\mathrm{kg})$ & $9 \cdot 1$ & $2 \cdot 3$ & $21 \cdot 5^{* *}$ & $4 \cdot 5$ & $12 \cdot 0^{*}$ & $2 \cdot 3$ & $14 \cdot 1$ & $5 \cdot 2$ \\
\hline Arm circumference $(\mathrm{mm})$ & 237 & 16 & 320 & 29 & 264 & 25 & 272 & 26 \\
\hline BMI & $17 \cdot 6^{*}$ & $1 \cdot 0$ & $26 \cdot 2^{*}$ & $2 \cdot 4$ & $19 \cdot 6$ & 1.6 & $21 \cdot 1$ & $2 \cdot 7$ \\
\hline \multicolumn{9}{|l|}{ May-Jun (preharvest) } \\
\hline Wt $(\mathrm{kg})$ & $44 \cdot 1$ & 4.9 & $63 \cdot 3$ & $7 \cdot 3$ & $49 \cdot 0$ & $5 \cdot 0$ & $53 \cdot 3$ & $7 \cdot 0$ \\
\hline Percentage fat & $19 \cdot 7$ & $4 \cdot 8$ & $31 \cdot 2$ & $4 \cdot 5$ & $25 \cdot 2$ & $4 \cdot 9$ & $26 \cdot 2$ & $5 \cdot 0$ \\
\hline Fat mass $(\mathrm{kg})$ & $8 \cdot 6$ & $2 \cdot 3$ & $19 \cdot 9$ & $4 \cdot 6$ & $12 \cdot 4$ & $3 \cdot 2$ & $14 \cdot 2$ & $4 \cdot 2$ \\
\hline Arm circumference (mm) & 241 & 19 & 315 & 25 & 264 & 23 & 266 & 22 \\
\hline BMI & $17 \cdot 3$ & $1 \cdot 1$ & $25 \cdot 5$ & $2 \cdot 5$ & $19 \cdot 7$ & 1.4 & $21 \cdot 0$ & $2 \cdot 6$ \\
\hline \multicolumn{9}{|l|}{ Aug-Oct (post-harvest) } \\
\hline Wt (kg) & $44 \cdot 3$ & $4 \cdot 9$ & $63 \cdot 6$ & $7 \cdot 4$ & $49 \cdot 3$ & $4 \cdot 5$ & $53.9 *$ & $7 \cdot 0$ \\
\hline Percentage fat & \multicolumn{2}{|c|}{ NM } & \multicolumn{2}{|c|}{ NM } & $25 \cdot 4$ & $4 \cdot 7$ & $27 \cdot 5 * * \dagger \dagger$ & $5 \cdot 4$ \\
\hline Fat mass $(\mathrm{kg})$ & \multicolumn{2}{|c|}{ NM } & \multicolumn{2}{|l|}{ NM } & $12 \cdot 6$ & $3 \cdot 0$ & $15 \cdot 0^{* *+\dagger}$ & $4 \cdot 6$ \\
\hline Arm circumference $(\mathrm{mm})$ & \multicolumn{2}{|c|}{ NM } & \multicolumn{2}{|l|}{ NM } & 263 & 22 & 271 & 25 \\
\hline BMI & $17 \cdot 3$ & $1 \cdot 1$ & $25 \cdot 8$ & $2 \cdot 5$ & $19 \cdot 8$ & $1 \cdot 4$ & $21 \cdot 2^{*}$ & $2 \cdot 6$ \\
\hline
\end{tabular}

NM, not measured; BMI, body mass index (wt/height ${ }^{2}$ ).

Mean values were significantly different from those for May-June: ${ }^{*} P<0.05,{ }^{* *} P<0.01$.

Mean values were significantly different from those for January-February: $\dagger \dagger P<0 \cdot 01$.

$\ddagger$ For details of subjects and procedures, see Table 1 and pp. $690-693$.

increased by 0.6 (sD 0.8$) \mathrm{kg}(P<0.05)$ in August-October (post-harvest); their fat mass also increased significantly.

Changes in body weight in relation to the three seasons of measurement are shown in Fig. 1.

\section{Energy intake and physical activity level}

Results of energy intake measurements are presented in Table 3 . The energy intake of all four groups of women was lower during the preharvest season in May-June than during the post-harvest seasons in January-February. However, only subjects with a BMI $<18$ and subjects who had shown a large preharvest weight loss showed statistically significant seasonal changes in energy intake. Energy intake during the preharvest season in May-June of subjects with a BMI $<18$ was 0.97 (SD 1.57) MJ $(231$ (SD 375) kcal)/d $(P<0.05$ ) lower than the intake during the post-harvest season in January-February. The energy intake in August-October (post-harvest) of subjects who had shown a large preharvest weight loss was 1.49 (SD 1.88) MJ (357 (SD 449) kcal)/d lower than the intake in January-February $(P$ $<0.05)$. Energy intake expressed per unit body weight of the four groups showed large differences. During the preharvest season the intake of subjects with a BMI $<18$ was $38 \mathrm{~kJ}$ $(9 \mathrm{kcal}) / \mathrm{kg}$ per $\mathrm{d}$ higher $(P<0.01)$ than the intake of subjects with a BMI $>23$.

PAL during the three seasons is shown in Table 3 . There were no significant seasonal 


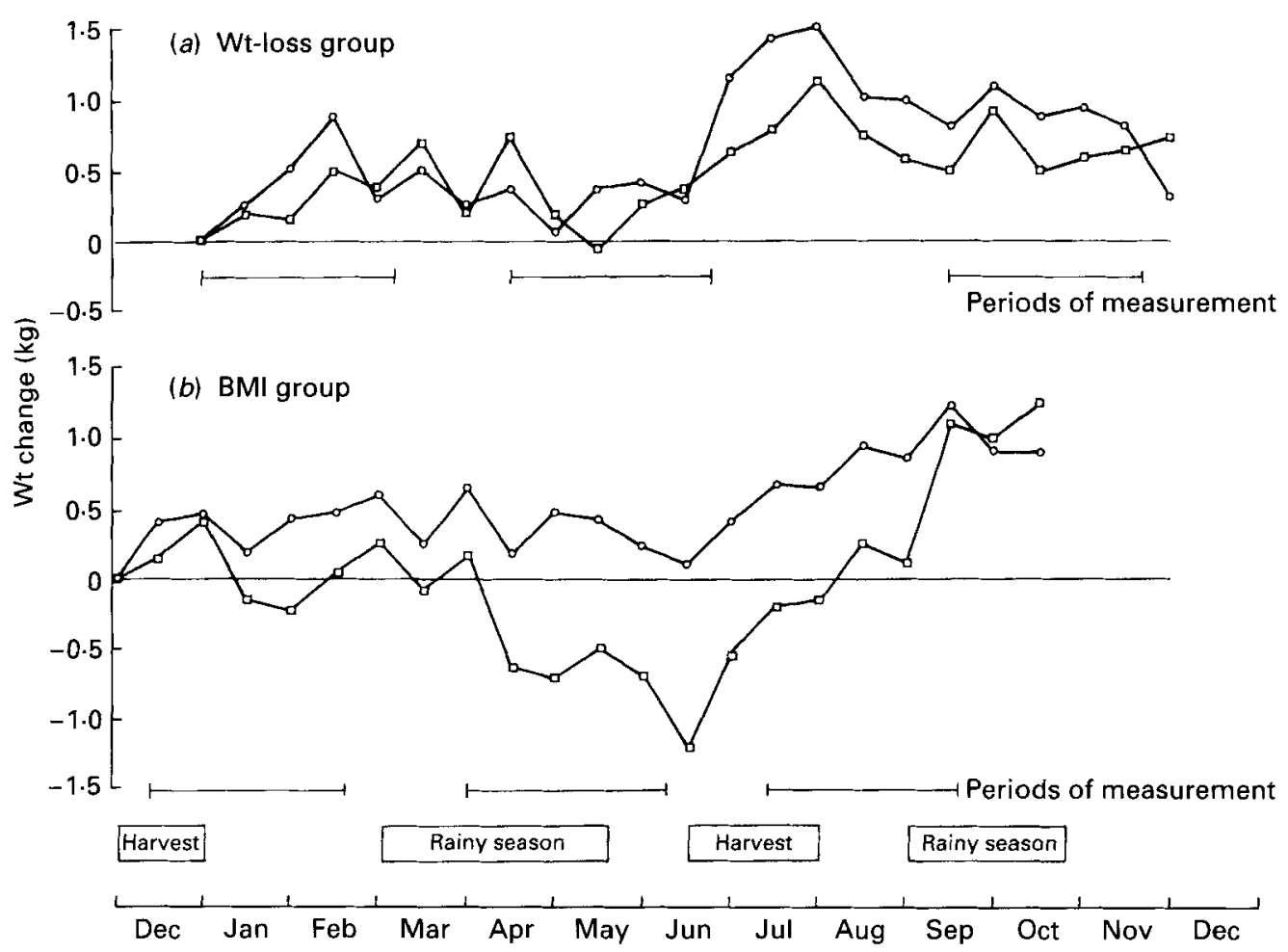

Fig. 1. Body-weight changes throughout a 1-year cycle for four groups of rural Beninese women. (a) Weight-loss group: (O), Large preharvest weight loss $(n 15)$; $(\square)$, small preharvest weight loss $(n 18)$. (b) Body mass index (weight/height ${ }^{2}$; BMI) group: $(\bigcirc), \mathrm{BMI}<18(n 18) ;(\square), \mathrm{BMI}>23(n 16)$. For details of subjects and procedures, see Table 1 and pp. 690-693.

changes in PAL in any of the four groups of subjects. The lowest PAL was $1.66 \times$ BMR for subjects with a $\mathrm{BMI}>23$ during the post-harvest season in January--February. This value was significantly lower than the level of $1.74 \times \mathrm{BMR}$ for subjects with a BMI $<18$ in the same season $(P<0.05)$.

\section{Basal metabolic rate}

Results of the BMR measurements are presented in Table 4. Subjects with a BMI $<18$ showed significant seasonal changes in BMR. This was not so for the other three groups of subjects. BMR of subjects with a BMI $<18$ during the preharvest season in May-June was lower $(P<0.05)$ than the values in the other two seasons. The decrease remained significant when BMR was expressed per unit body weight. BMR in May-June (preharvest) was 2.9 (SD 6.7) J $(0.7$ (SD 1.6) cal) $/ \mathrm{kg}$ per min lower $(P<0.05)$ than that in August-October (post-harvest). BMR per unit fat-free mass in May-June was not statistically significantly lower than in January-February $(P=0 \cdot 11)$.

BMR of subjects with a BMI $>23$ of 66.0 (SD 7.9) J (15.8 (SD 1.9) cal) $/ \mathrm{kg}$ per min (postharvest, January-February) was significantly lower $(P<0.01)$ than the value of 80.7 (SD 6.7) $\mathrm{J}(19.3$ (SD 1.6) cal) $/ \mathrm{kg}$ per min for subjects with a BMI $<18$ in the same season, the difference was no longer significant when BMR was expressed per unit fat-free mass. 
Table 3. Energy intake and physical activity level $(P A L)$ in three different seasons for rural Beninese women $\ddagger$

(Mean values and standard deviations)

\begin{tabular}{|c|c|c|c|c|c|c|c|c|}
\hline \multirow[b]{3}{*}{ Season } & \multicolumn{4}{|c|}{ BMI group } & \multicolumn{4}{|c|}{$\begin{array}{l}\text { Wt-loss group (preharvest wt loss } \\
\text { in previous year) }\end{array}$} \\
\hline & \multicolumn{2}{|c|}{$\begin{array}{l}\mathrm{BMI}<18 \\
\quad(n 18)\end{array}$} & \multicolumn{2}{|c|}{$\begin{array}{c}\mathrm{BMI}>23 \\
(n 16)\end{array}$} & \multicolumn{2}{|c|}{$\begin{array}{l}\text { Small } \\
(n 18)\end{array}$} & \multicolumn{2}{|c|}{$\begin{array}{l}\text { Large } \\
(n 15)\end{array}$} \\
\hline & Mean & SD & Mean & SD & Mean & SD & Mean & SD \\
\hline \multicolumn{9}{|c|}{ Jan-Feb (post-harvest) } \\
\hline \multicolumn{9}{|l|}{ Energy intake: } \\
\hline $\mathrm{MJ} / \mathrm{d}$ & $7 \cdot 90$ & 1.96 & 8.66 & $2 \cdot 32$ & $8 \cdot 11$ & $2 \cdot 15$ & $8 \cdot 30$ & $2 \cdot 37$ \\
\hline $\begin{array}{l}\mathrm{kJ} / \mathrm{kg} \text { per } \mathrm{d} \\
\text { PAL } \S\end{array}$ & 180 & 50 & 138 & 38 & 167 & 42 & 155 & 50 \\
\hline$\times$ BMR & $1 \cdot 74$ & 0.12 & 1.66 & $0 \cdot 11$ & 1.73 & 0.13 & 1.73 & $0 \cdot 16$ \\
\hline \multicolumn{9}{|c|}{ May-Jun (preharvest) } \\
\hline \multicolumn{9}{|c|}{ Energy intake: } \\
\hline $\mathrm{MJ} / \mathrm{d}$ & $6.94 * \dagger$ & $1 \cdot 20$ & $7 \cdot 56$ & 1.9 & $7 \cdot 46$ & 1.53 & $7 \cdot 31^{*}$ & 2.07 \\
\hline $\begin{array}{l}\mathrm{kJ} / \mathrm{kg} \text { per } \mathrm{d} \\
\text { PAL } \S\end{array}$ & $159^{*} \dagger$ & 29 & 121 & 29 & 155 & 33 & $138^{*}$ & 42 \\
\hline$\times \mathrm{BMR}$ & 1.73 & 0.08 & $1 \cdot 70$ & $0 \cdot 14$ & 1.73 & $0 \cdot 12$ & 1.74 & $0 \cdot 10$ \\
\hline \multicolumn{9}{|c|}{ Aug-Oct (post-harvest) } \\
\hline \multicolumn{9}{|c|}{ Energy intake: } \\
\hline $\mathrm{MJ} / \mathrm{d}$ & $7 \cdot 78$ & $1 \cdot 58$ & 7.96 & 1.49 & 8.04 & 1.63 & $6.81^{*}$ & 1.69 \\
\hline $\begin{array}{l}\mathrm{kJ} / \mathrm{kg} \text { per } \mathrm{d} \\
\text { PAL\& }\end{array}$ & 176 & 42 & 125 & 21 & 163 & 33 & $125^{*}$ & 29 \\
\hline$\times$ BMR & $1 \cdot 76$ & 0.09 & 1.73 & $0 \cdot 15$ & 1.78 & $0 \cdot 15$ & $1 \cdot 78$ & $0 \cdot 11$ \\
\hline
\end{tabular}

BMI, body mass index (wt/height ${ }^{2}$ ).

Mean values were significantly different from those for January-February: ${ }^{*} P<0.05$.

Mean values were significantly different from those for August-October: $\dagger P<0.05$.

\$ For details of subjects and procedures, see Table 1 and pp. 690-693.

$\$$ Total daily energy requirement expressed relative to BMR.

\section{DISCUSSION}

Normally during the preharvest season, if food intake is decreased, body weight is lost in order to provide fuel to buffer the effects of food shortage. As a consequence energy expenditure is lower. Some groups of individuals within a rural community hardly lose weight (Schultink et al. 1990); therefore, we wanted to investigate whether some individuals show metabolic adaptation in order to decrease energy expenditure and through that prevent large body-weight losses during the preharvest season. The necessity to decrease energy expenditure would only exist if energy intake during the preharvest season decreases markedly compared with the energy intake during the post-harvest season. In the present study the energy intake of all four groups of women during the preharvest season in May-June was lower than energy intake during the post-harvest season in January-February, although this decrease was statistically significant in only two groups. The fall in energy intake between the post- and preharvest seasons ranged from about $0.67 \mathrm{MJ}$ $(160 \mathrm{kcal}) / \mathrm{d}$ to $1.09 \mathrm{MJ}(260 \mathrm{kcal}) / \mathrm{d}$. This decrease in energy intake during the preharvest season is comparable with results from other studies among rural African women in Senegal (Rosetta, 1985), Ethiopia (Ferro-Luzzi et al. 1990) and The Gambia (Prentice et al. 1981) where decreases in energy intake during the preharvest season were reported, ranging from $0.54 \mathrm{MJ}(130 \mathrm{kcal}) / \mathrm{d}$ to $1.67 \mathrm{MJ}(400 \mathrm{kcal}) / \mathrm{d}$. Energy intake expressed per unit body 
Table 4. Basal metabolic rate $(B M R)$ in three different seasons for rural Beninese women $\dagger$

(Mean values and standard deviations)

\begin{tabular}{|c|c|c|c|c|c|c|c|c|}
\hline \multirow[b]{3}{*}{ Season } & \multicolumn{4}{|c|}{ BMI group } & \multicolumn{4}{|c|}{$\begin{array}{l}\text { Wt-loss group (preharvest wt loss } \\
\text { in previous year) }\end{array}$} \\
\hline & \multicolumn{2}{|c|}{$\begin{array}{c}\mathrm{BMI}<18 \\
\quad(n 18)\end{array}$} & \multicolumn{2}{|c|}{$\begin{array}{c}\mathrm{BMI}>23 \\
(n 16)\end{array}$} & \multicolumn{2}{|c|}{$\begin{array}{l}\text { Small } \\
(n 18)\end{array}$} & \multicolumn{2}{|c|}{$\begin{array}{l}\text { Large } \\
(n 15)\end{array}$} \\
\hline & Mean & SD & Mean & SD & Mean & SD & Mean & SD \\
\hline \multicolumn{9}{|l|}{ Jan-Feb (post-harvest) } \\
\hline \multicolumn{9}{|l|}{ BMR } \\
\hline $\mathrm{MJ} / \mathrm{d}$ & $5 \cdot 16$ & 0.57 & $6 \cdot 11$ & 0.54 & 5.42 & 0.63 & $5 \cdot 82$ & $0-60$ \\
\hline $\mathrm{kJ} / \mathrm{min}$ & $3 \cdot 59$ & 0.38 & $4 \cdot 22$ & $0 \cdot 38$ & 3.76 & 0.42 & $4 \cdot 05$ & 0.42 \\
\hline $\mathrm{J} / \mathrm{kg}$ per $\min$ & $80 \cdot 7$ & $6 \cdot 7$ & $66 \cdot 0$ & $7 \cdot 9$ & $77 \cdot 7$ & $9 \cdot 6$ & 76.9 & $10 \cdot 0$ \\
\hline $\mathrm{J} / \mathrm{kg}$ FFM per min & $101 \cdot 2$ & $7 \cdot 5$ & 98.6 & 9.6 & $102 \cdot 8$ & $10 \cdot 9$ & $102 \cdot 8$ & $10-5$ \\
\hline \multicolumn{9}{|l|}{ May-Jun (preharvest) } \\
\hline \multicolumn{9}{|l|}{ BMR } \\
\hline $\mathrm{MJ} / \mathrm{d}$ & $4 \cdot 94^{*}$ & 0.65 & $6 \cdot 04$ & 0.50 & $5 \cdot 48$ & 0.66 & $5 \cdot 78$ & $0 \cdot 72$ \\
\hline $\mathrm{kJ} / \mathrm{min}$ & $3.43^{*}$ & 0.46 & $4 \cdot 18$ & $0 \cdot 33$ & 3.80 & 0.46 & 4.01 & 0.38 \\
\hline $\mathrm{J} / \mathrm{kg}$ per $\min$ & $78 \cdot 6^{*}$ & $4 \cdot 6$ & $66 \cdot 9$ & $8 \cdot 4$ & $78 \cdot 6$ & $9 \cdot 2$ & 76.5 & $6 \cdot 3$ \\
\hline $\mathrm{J} / \mathrm{kg} \mathrm{FFM}$ per $\min$ & $97 \cdot 8$ & $8 \cdot 4$ & $97 \cdot 4$ & $7 \cdot 9$ & $104 \cdot 1$ & $12 \cdot 1$ & $102 \cdot 8$ & $5 \cdot 4$ \\
\hline \multicolumn{9}{|l|}{ Aug-Oct (post-harvest) } \\
\hline \multicolumn{9}{|l|}{ BMR } \\
\hline $\mathrm{MJ} / \mathrm{d}$ & $5 \cdot 15$ & 0.62 & $6 \cdot 10$ & 0.58 & 5.53 & 0.72 & $5 \cdot 64$ & 0.59 \\
\hline $\mathrm{kJ} / \mathrm{min}$ & $3 \cdot 55$ & $0 \cdot 42$ & $4 \cdot 22$ & 0.42 & $3 \cdot 85$ & 0.50 & $3 \cdot 93$ & $0-42$ \\
\hline $\mathrm{J} / \mathrm{kg}$ per $\min$ & $81 \cdot 5$ & $7 \cdot 9$ & $67 \cdot 3$ & $9 \cdot 6$ & $78 \cdot 6$ & $9 \cdot 6$ & 7.3 .6 & $6 \cdot 7$ \\
\hline $\mathrm{J} / \mathrm{kg}$ FFM per $\min$ & \multicolumn{2}{|c|}{$\mathrm{NM}$} & \multicolumn{2}{|c|}{ NM } & 104.9 & $9 \cdot 6$ & $101 \cdot 2$ & 5.9 \\
\hline
\end{tabular}

NM, not measured; BMI, body mass index (wt/height ${ }^{2}$ ); FFM, fat-free mass.

Mean values were significantly different from those in post-harvest seasons in January-February and August-October: ${ }^{*} P<0.05$.

$\dagger$ For details of subjects and procedures, see Table 1 and pp. 690-693.

weight for Ethiopian women during the preharvest season was $0.17 \mathrm{MJ}(40 \mathrm{kcal}) / \mathrm{kg}$ per d (Ferro-Luzzi et al. 1990) compared with a lower value of $0.14 \mathrm{MJ}$ (34 kcal) $/ \mathrm{kg}$ per d which is about the average for all four groups of subjects in the present study during the preharvest season.

When the level of energy intake falls below the level of energy expenditure during a prolonged period of time, energy expenditure might be reduced by changing the activity pattern. Although energy intake decreased during the preharvest season in the present study, PAL did not change significantly during the different seasons throughout the year in any of the four groups. Since it was our intention only to investigate whether seasonal changes in PAL would occur, no comparison will be made here between the energy intake and PAL.

Considering the fall in energy intake and the unchanged energy expenditure a loss in body weight would be expected during the preharvest season. The group of subjects with a BMI $>23$ showed a decrease in body weight during the preharvest season in May-June consisting mainly of fat mass. Also, subjects with a BMI $<18$ decreased body weight during the preharvest season. Subjects who had shown small preharvest weight loss in the previous year experienced no significant weight change, which corresponds with the nonsignificant changes in energy intake. Subjects who had shown a large preharvest weight loss in the previous year did not decrease their weight significantly during the preharvest season but weight increased markedly during the post-harvest period in August-October. 


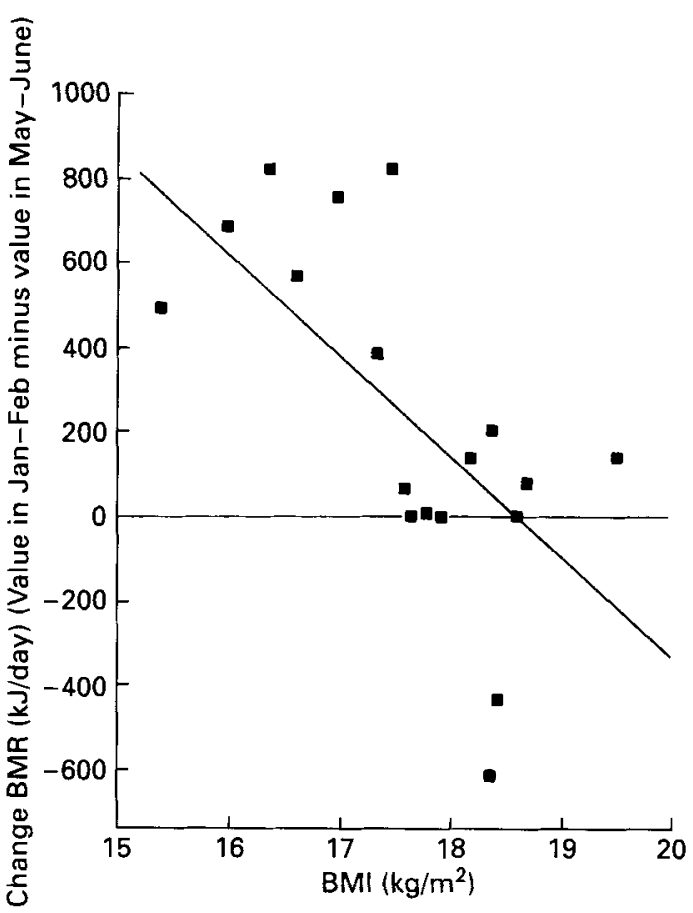

Fig. 2. Relationship between body mass index (weight/height ${ }^{2} ; \mathrm{BMI}$ ) and the decrease in BMR for rural Beninese women with an initial BMI $<18(r 0.64 ; y=4653-253 x ; P<0.01)$. The decrease in BMR $(\mathrm{kJ} / \mathrm{d})$ is calculated as the value in the post-harvest season minus the value in the preharvest season. The presented BMI values are the means over the measurement periods. For details of subjects and procedures, see Table 1 and pp. 690-693.

BMR values in the present study vary from about $67 \mathrm{~J}(16 \mathrm{cal}) / \mathrm{kg}$ per $\min (\mathrm{BMI}>23)$ to $84 \mathrm{~J}(20 \mathrm{cal}) / \mathrm{kg}$ per min $(\mathrm{BMI}<18)$. They are comparable with BMR values reported for other rural women in Africa, which are: Ethiopian women $84 \mathrm{~J}(20 \mathrm{cal}) / \mathrm{kg}$ per min (Ferro-Luzzi et al. 1990), Gambian women $79 \mathrm{~J}$ (19 cal)/kg per min (Lawrence et al. 1984), Beninese women $75 \mathrm{~J}$ (18 cal) $/ \mathrm{kg}$ per min (Schultink et al. 1990). A predicted BMR for subjects with small preharvest weight loss using the World Health Organization (1985) equations and their body weight in January-February is $5.25 \mathrm{MJ}(1250 \mathrm{kcal}) / \mathrm{d}$. Our measured value of $5.42 \mathrm{MJ}(1297 \mathrm{kcal}) / \mathrm{d}$ is $104 \%$ of the predicted value. When BMR is expressed per unit fat-free mass the values are about $96 \mathrm{~J}(23 \mathrm{cal}) / \mathrm{min}-105 \mathrm{~J}(25 \mathrm{cal}) / \mathrm{min}$ and are comparable with reported values for Gambian women of $96 \mathrm{~J}(23 \mathrm{cal}) / \mathrm{min}$ (Lawrence et al. 1988).

Only lean women with a BMI $<18$ changed their BMR significantly throughout the year. The BMR of these lean women was $4.3 \%$ lower during the preharvest season than that during the other two seasons. This decrease was not only caused by a loss of body weight. The decrease in BMR expressed per unit body weight during the preharvest season is still about $3 \%$, which represents a statistically significant seasonal change. Within the group of women with a BMI $<18$ a correlation existed between BMI and the decrease in BMR (Fig. $2)$. Very thin women with a BMI $<17$ showed a large reduction in BMR during the preharvest season (Table 5). BMR of these very thin women changed from 86.9 (SD 5.0$) \mathrm{J}$ $(20.8(\mathrm{SD} 1.2) \mathrm{cal}) / \mathrm{kg}$ per $\min$ in the post-harvest season to 76.9 (SD 4.2$) \mathrm{J}(18.4$ $(\mathrm{SD} 1.0) \mathrm{cal}$ ) $/ \mathrm{kg}$ per min in the preharvest season, which is a $12 \%$ decrease. This change in BMR between the post-harvest and preharvest seasons represents a daily saving in energy 
Table 5. Basal metabolic rate $(B M R)$, energy intake and physical activity level $(P A L)$ in three different seasons for rural Beninese women with a $B M I<17$ \$

(Mean values and standard deviations for five subjects)

\begin{tabular}{|c|c|c|c|c|c|c|}
\hline \multirow[t]{2}{*}{ Season... } & \multicolumn{2}{|c|}{$\begin{array}{c}\text { Jan-Feb } \\
\text { Post-harvest }\end{array}$} & \multicolumn{2}{|c|}{$\begin{array}{l}\text { May-June } \\
\text { Preharvest }\end{array}$} & \multicolumn{2}{|c|}{$\begin{array}{c}\text { Aug-Oct } \\
\text { Post-harvest }\end{array}$} \\
\hline & Mean & $\mathrm{SD}$ & Mean & SD & Mean & $\mathrm{SD}$ \\
\hline \multicolumn{7}{|l|}{ BMR } \\
\hline $\mathrm{MJ} / \mathrm{d}$ & 5.08 & 0.61 & $4.45^{*} \dagger$ & 0.56 & 4.97 & 0.50 \\
\hline $\mathrm{kJ} / \mathrm{min}$ & $3 \cdot 51$ & 0.42 & $3.09 * \dagger$ & 0.38 & $3 \cdot 43$ & $0-33$ \\
\hline $\mathrm{J} / \mathrm{kg}$ per $\min$ & 86.9 & $5 \cdot 0$ & $76.9 *+$ & $4 \cdot 2$ & 84.9 & $7 \cdot 5$ \\
\hline $\mathrm{J} / \mathrm{kg} \mathrm{FFM} \mathrm{per} \mathrm{min}$ & $103 \cdot 7$ & $6 \cdot 3$ & $92 \cdot 4^{*}$ & $6 \cdot 3$ & \multicolumn{2}{|c|}{ NM } \\
\hline \multicolumn{6}{|l|}{ Energy intake } & 1.87 \\
\hline \multicolumn{7}{|l|}{ PAL\$ } \\
\hline$\times$ BMR & 1.70 & $0 \cdot 11$ & $1 \cdot 70$ & 0.06 & 1.78 & $0 \cdot 08$ \\
\hline
\end{tabular}

NM, not measured; BMI, body mass index (wt/height ${ }^{2}$ ).

Mean values were significantly different from those in January-February: ${ }^{*} P<0.05$.

Mean values were significantly different from those in August-October: $\uparrow P<0.05$.

$\$$ For details of subjects and procedures, see Table I and pp. 690-693.

$\S$ Total daily energy requirement expressed relative to BMR.

expenditure of $0.63 \mathrm{MJ}(150 \mathrm{kcal}) / \mathrm{d}$, covering about $30 \%$ of the fall in energy intake. Metabolic adaptation during the preharvest period has also been reported for lean rural Ethiopian women with a BMI of 18.4 (SD 1.6) (Ferro-Luzzi et al. 1990). The daily energy intake of these women dropped from $9.24 \mathrm{MJ}(2210 \mathrm{kcal}) / \mathrm{d}$ to $8.55 \mathrm{MJ}(2045 \mathrm{kcal}) / \mathrm{d}$ while their BMR decreased from $86.9 \mathrm{~J}(20.8 \mathrm{cal}) / \mathrm{kg}$ per min to $78.6 \mathrm{~J}(18.8 \mathrm{cal}) / \mathrm{kg}$ per min in the same period, which is equal to the decrease in BMR in the women with a BMI $<17$ in the present study. In a previous study among rural Beninese women (BMI $21 \cdot 1$ (SD 2.0)) energy intake during the preharvest season decreased by about $1.25 \mathrm{MJ}(300 \mathrm{kcal}) / \mathrm{d}$ compared with the post-harvest season and arrived at a level of $6.52 \mathrm{MJ}(1550 \mathrm{kcal}) / \mathrm{d}$ (Schultink et al. 1990). This large seasonal change to a low level of energy intake did not provoke a change in BMR, nor a change in physical activity level.

Sukhatme \& Margen (1982) postulated that individuals can change their metabolic rate at all times in response to a sustained change in energy intake without changing body energy stores or physical activity. The results obtained in the present study do not support this hypothesis. Only thin women with a low BMI showed metabolic adaptation to a loss of body weight, while women with larger body energy stores only decreased body weight in response to a moderate reduction in energy intake. However, there are limits to the amount of weight which an individual can lose if good health is to be maintained. It is argued that a BMI below 17 constitutes a risk to health and could lead to an impaired physical capacity (James et al. 1988). During periods when food availability is modestly restricted, as may occur during preharvest seasons in developing countries, the present results suggest that individuals do not change their PAL but decrease their body weight in order to re-establish energy balance. However, if a loss in body weight would represent a danger to health and an impairment to physical capacity, which is probably the case with a $\mathrm{BMI}<17$, a metabolic adaptation occurs to lower energy expenditure.

This study was carried out in the framework of the Beninese-Netherlands inter-university cooperation project, in which Wageningen Agricultural University participates. The staff 
of the Section of Nutrition and Food Science, Faculty of Agricultural Sciences, Benin National University have been very helpful throughout the study period, and the authors thank Dr M. C. Nago, Dr H. F. Nouwakpo, H. van Wijk and Dr F. de Koning for their continuous interest and excellent support. The field assistance of Nicole Jacobs, Dorine Huisman, Romke Vrijburg, Andi Tan, Christianne Hupkens and Anja Huisman was invaluable. Supported by the Netherlands Foundation for the Advancement of Tropical Research (WOTRO grant W96-73).

\section{REFERENCES}

Annegers, J. F. (1973). Seasonal food shortages in West-Africa. Ecology of Food and Nutrition 2, $251-257$.

Bingham, S. A., Paul, A. A., Haraldsdottir, J., Loken, E. B. \& van Staveren, W. A. (1988). Methods for data collection at an individual level. In Manual on Methodology for Food Consumption Studies [M. E. Cameron and W. A. van Staveren, editors]. Oxford: Oxford University Press.

Bleiberg, F. M., Brun, T. A. \& Goihman, S. (1980). Duration of activities and energy expenditure of female farmers in dry and rainy seasons in Upper Volta. British Journal of Nutrition 43, 71-82.

Brun, T., Bleiberg, F. \& Goihman, S. (1981). Energy expenditure of male farmers in dry and rainy seasons in Upper-Volta. British Journal of Nutrition 45, 67-82.

Durnin, J. V. G. A. \& Passmore, R. (1967). Energy, Work and Leisure. London: Heinemann Educational Books Ltd.

Durnin, J. V. G. A. \& Womersley, J. (1974). Body fat assessed from total body density and its estimation from skinfold thickness: measurements on 418 men and women aged from 16 to 72 years. British Journal of Nutrition 32, 77-97.

Ferro-Luzzi, A. (1990). Social and public health issues in adaptation to low energy intakes. American Journal of Clinical Nutrition 51, 309-315.

Ferro-Luzzi, A., Pastore, G. \& Sette, S. (1987). Seasonality in energy metabolism. In Chronic Energy Deficiency: Consequen:es and Related Issues, pp. 37-58 [B. Schürch and N. S. Scrimshaw, editors]. Lausanne: International Dietary Energy Consultative Group (IDECG).

Ferro-Luzzi, A., Scaccini, C., Taffese, S., A berra, B. \& Demeke, T. (1990). Seasonal energy deficiency in Ethiopian rural women. European Journal of Clinical Nutrition 44, Suppl.1, 7-18.

James, W. P. T., Ferro-Luzzi, A. \& Waterlow, J. C. (1988). The definition of chronic energy deficiency in adults. European Journal of Clinical Nutrition 42, 969-981.

James, W. P. T. \& Schofield, E. C. (1990). Human Energy Requirements. Oxford: Oxford University Press.

Keys, A., Brozek, J., Henschel, A., Mickelsen, O. \& Taylor, H. L. (1950). Biology of Human Starvation. Minneapolis: University of Minnesota Press.

Lawrence, M., Lawrence, F., Lamb, W. H. \& Whitehead, R. G. (1984). Maintenance energy cost of pregnancy in rural Gambian women, and influence of dietary status. Lancet ii, 363-365.

Lawrence, M., Thongprasert, K. \& Durnin, J. V. G. A. (1988). Between group differences in basal metabolic rates: an analysis of data collected in Scotland, the Gambia and Thailand. European Journal of Clinical Nutrition $\mathbf{4 2}$, $877-891$.

Platt, B. S. (1979). Tables of representative values of foods commonly used in tropical countries, Medical Research Council. Special Report Series no. 302. London: H.M. Stationery Office.

Prentice, A. M., Whitehead, R. G., Roberts, S. B. \& Paul, A. A. (1981). Long term energy balance in child-bearing Gambian women. American Journal of Clincal Nutrition 34, 2790-2799.

Rosetta, L. (1985). Sex differences in seasonal variations of the nutritional status of Serere adults in Senegal. Ecology of Food and Nutrition 18, 231-244.

Schultink, J. W., Klaver, W., van Wijk, H., van Raaij, J. M. A. \& Hautvast, J. G. A. J. (1990). Body weight changes and basal metabolic rates of rural Beninese women during seasons with different energy intakes. European Journal of Clinical Nutrition 44, Suppl.1, 31-40.

Snedecor, G. W. \& Cochran, W. G. (1980). Statistical Methods, 7th ed., p. 534. Iowa: Iowa State University Press.

SPSS Inc. (1986). SPSS/PC+ for the IBM PC/XT/AT, 1986 ed. Chicago, IL: SPSS Inc.

Sukhatme, P. V. \& Margen, S. (1982). Autoregulatory homestatic nature of energy balance. American Journal of Clincal Nutrition 35, 355-365.

Teokul, W., Payne, P. \& Dugdale, A. (1986). Seasonal variations in nutritional status in rural areas of developing countries: a review of the literature. Food and Nutrition Bulletin 8, 7-10.

Weir, J. B. de V. (1949). New methods for calculating metabolic rate with special reference to protein metabolism. Journal of Physiology 109, 1-11.

Woot Tsuen, W. L. (1970). Table de composition des aliments à Tusage de l'Afrique (Food composition tables for Africa), 1st ed. Rome: FAO/WHO.

World Health Organization. (1985). Energy and Protein Requirements. Report on a Joint FAO/WHO/UNU Expert Consultation. Technical Report Series no. 724, p. 206. Geneva:WHO. 